\title{
Regional Seasonality in Australian House and Apartment Price Returns
}

\author{
ABBAS VALADKHANI ${ }^{*}$, RUSSELL SMYTH $^{* *}$ and ANDREW WORTHINGTON ${ }^{\dagger}$ \\ * Department of Accounting, Economics and Finance, Swinburne University of Technology, \\ HawthornVIC 3122 Australia.Email: abbas@swin.edu.au \\ ** Department of Economics, Monash University, VIC 3800, Australia. Email: \\ Russell.Smyth@monash.edu \\ ${ }^{\dagger}$ Department of Accounting, Finance and Economics, Griffith University, Nathan, QLD 4111, \\ Australia.Email: a.worthington@griffith.edu.au
}

Valadkhani, A., Smyth, R., Worthington, A., (2016) Regional Seasonality in Australian House and Apartment Price Returns, Regional Studies, (Accepted: 16 May 2016, 5-Year Impact Factor $=2.372$ ) 


\section{Regional Seasonality in Australian House and Apartment Price Returns}

This paper examines regional seasonality in house and apartment price returns across all Australian capital cities from December 1995 to November 2015. The results suggest sizable seasonal effects for the very smallest and very largest regional capitals and that seasonal return variation is more significant for house than apartment returns. Further, the observed month-ofthe-year effects have undergone significant changes in almost all cities for both house and apartment returns since the global financial crisis (GFC). The discussion offers some reasons for the differences in seasonality between houses and apartments as well as between regions and over time.

Keywords: House and apartment prices, Seasonality, Australia.

JEL classifications: O18, R31, R51.

\section{INTRODUCTION}

Seasonality is a common characteristic of many time series in which the data experience regular and predictable changes over specific time intervals. While house buyers and sellers alike accept it as an article of faith that housing markets display at least some seasonality (CROUCHER, 2014), understanding seasonality in price returns remains important for several reasons. First, seasonal influences affect demand, supply, and any corresponding price fluctuations. Regional differences in seasonality also potentially affect regional variations in housing prices (LERBS and OBERST, 2014). For example, spring/summer and autumn/winter housing markets in the United Kingdom (UK) and the United States (US) are argued to experience systematic above-trend increases in both prices and transactions during the second (June) and third (September) quarters (the so- 
called 'hot season') and below-trend falls during the fourth (December) and first (March) quarters (the so-called 'cold season').

Second, there are multiple interactions between housing markets and the economy as a whole. For example, housing and mortgage markets play an important role in influencing the economy's cyclical dynamics via monetary policy (KUETHE and PEDE, 2011). Through this, seasonal fluctuations in housing markets influence a range of macroeconomic indicators.

Lastly, seasonality in housing returns has important implications for buyers and sellers. Seasonality, as exemplified by month-of-the-year effects, represents calendar anomalies that contradict the (weak-form) efficient market hypothesis, such that returns (and thus prices) can be predicted using historical information. Such calendar anomalies provide opportunities for buyers or sellers to make potential abnormal gains.

A small, but influential, literature has emerged that tests seasonality in housing markets, primarily in the US and/or UK (CASE and SHILLER, 1989; ROSENTHAL, 2006; NGAI and TENREYRO, 2014). These studies complement a closely related literature that tests for calendar effects in real-estate-related securities, such as real estate investment trusts, (COLWELL and PARK, 1990; HUI et al., 2013). Among the studies testing for calendar effects in housing markets, in the UK, Rosenthal (2006) used the Nationwide Building Society database of newly transacted dwellings to develop a monthly, quality-adjusted, regional house price series for the period 1991-2001, but found little evidence of either stochastic or deterministic seasonal effects. Conversely, NGAI and TENREYRo (2014) identified clear seasonal patterns in the US housing market.

The purpose of this paper is to examine regional differences in seasonality in house and apartment price returns across the eight Australian state and territory capital cities (Adelaide, 
Brisbane, Canberra, Darwin, Hobart, Melbourne, Perth and Sydney) using monthly data from December 1995 to November 2015. Australia provides an interesting case to examine seasonality compared with the more commonly studied US and UK housing markets. To start, Australia represents one of the most consistently expensive, unaffordable and strongest growing housing markets in the world (VALADKHANI et al., 2016). According to the most recent Annual International Housing Affordability Survey, housing in five of Australia's eight major metropolitan regions is rated as 'severely unaffordable', with Sydney and Melbourne, Australia's two largest cities, considered as the third- and sixth-least affordable cities in the world, respectively (DEMOGRAPHIA, 2015).

Further, while the Australian population is much smaller than either the US or the UK ${ }^{1}$, its landmass is similar in size to the US. As a result, Australia's population spreads across a diverse geographic area but with concentrated pockets in a few major geographically distant citiesalmost $70 \%$ of the population lives in one of the five-largest capital cities. Hence, compared with the housing market in the UK, one might expect that regional differences in economic conditions might be more reflective of house price movements, in particular, in the smaller, more remote, capital cities (AKIMOV et al., 2015). Specifically, in terms of seasonality in housing markets, in the northern hemisphere, seasonal fluctuations in housing prices link with different seasons of the year (NGAI and TENREYRO, 2014). Because of its sheer size, Australia has a huge variety of climates. For example, the southern capital cities (Sydney, Canberra, Melbourne, Hobart, Adelaide, and Perth) are located in temperate zones (although both Adelaide and Perth have a distinctly Mediterranean climate), while Brisbane and Darwin are respectively in subtropical and tropical zones. For this reason, compared with the southern capital cities, Brisbane and Darwin have higher temperatures and higher humidity throughout the year, as well as distinct wet and 
dry seasons, which may also potentially account for regional differences in seasonality in house returns. It is also likely that different weather patterns across the country induce seasonality in other economic variables, such as migration and leisure consumption, which, in turn, contribute to seasonality in real estate markets. For example, many retirees in the southern states retire to Queensland or spend the winter months at holiday apartments in Queensland.

This paper makes the following important contributions. First, it tests for seasonality in house and apartment returns for a housing market that is of international interest, not least given the extent and duration of the housing boom that has persisted, largely uninterrupted, for the last two decades. To do so, this paper employs a long time series, spanning December 1995 to November 2015, corresponding with much of Australia's ongoing long upward trend in housing prices.

The housing boom in Australia has focused attention on the housing market. However, there is little research on seasonality in Australian housing markets. Apart from those studies concerning seasonality in housing construction and financing as possible underlying causes of seasonality in housing prices (see, for instance, KARAMUJIC, 2012), there is only one, now rather dated, study by COSTELlo (2001). For the most part, COSTELlo (2001) confirms the presence of significant seasonal influences in housing prices, suggesting that the volume of transactions, and hence demand and prices, are greatest during the first quarter of the year and lowest during the last quarter. However, Costello (2001) uses transaction (quarterly) data from the Western Australian Valuer General's Office, so the analysis is limited to a single regional (state) market.

Second, this study employs SIRCA's CoreLogic RP database, which constitutes a rich source of data on Australian property prices, specifically developed as a reference asset for the settlement of exchange-traded property contracts. The accuracy of this database makes it preferable to other possible series, such as those maintained by the Australian Bureau of 
Statistics (ABS). One of the most attractive features of our database is that it contains housing price data at a higher frequency (monthly) than other alternative Australian housing price series that are available from the ABS or the Real Estate Institute of Australia (REIA).

Finally, for the first time this paper tests for seasonality in house and apartment returns separately. In addition to consumption, housing is an investment good (PIAZZESI et al., 2007). The purchase and sale of investment properties is likely unaffected by the time of the year when it is easiest to move and more likely to be influenced by taxation considerations, such as the end of the financial year (30 June). Certainly, investors treat different sorts of housing differently for investment purposes. In Australia, tax concessions surrounding negative gearing has made it attractive for many individuals to purchase and rent out investment properties. According to the Australian Tax Office, in 2010, 10\% of Australian taxpayers were negatively geared property owners (COLEBATCH, 2010). It is also more likely that apartments are investment properties. This raises the possibility of differing month-of-the year effects across houses and apartments.

\section{EMPIRICAL METHODOLOGY}

If a month-of-the-year effect holds, house and apartment price returns will in part be dependent on the month observed. Following the approach adopted in HuI et al.'s (2013) analysis, in which they test three well-known calendar effects (day of-the-week, month-of-the-year, and sell-in-May effects) in real estate security indices across 20 countries, this paper specifies a $k$-order autoregressive model augmented with 12 dummy variables to capture any fixed calendar effects: ${ }^{2}$

$$
\Delta \operatorname{Ln}\left(P_{t}\right)=\alpha+\sum_{i=2}^{12} \tilde{\beta}_{i} M_{i t}+\sum_{i=1}^{k} \eta_{i} \Delta \operatorname{Ln}\left(P_{t-i}\right)+\varepsilon_{t}
$$

where $P_{t}$ denotes monthly house/apartment prices at time $t, \alpha$ is a constant, $M_{i t}$ is a dummy variable that takes the value of one in month $i$ and zero otherwise (excluding the reference 
month), $\Delta L n P_{t-i}$ is the $i^{t h}$-period lagged value of monthly house/apartment returns, $\tilde{\beta}$ and $\eta$ are parameters to be estimated and $\varepsilon$ is the error term.

To avoid the dummy variable trap arising from perfect multicollinearity between the 12 monthly dummy variables, some studies (e.g. HuI et al. 2013) exclude a desired or arbitrary month as a benchmark while retaining the intercept $(\alpha)$. In equation (1) the intercept is retained and January is excluded, thus each $\tilde{\beta}_{i}$ coefficient is regarded as a differential intercept coefficient. In this model, $\tilde{\beta}_{i}$ shows by how much the value of the intercept term of a given month (the category with a value of one) differs from the intercept coefficient of the benchmark or omitted reference category (January). By excluding the intercept from equation (1), all 12 dummy variables (capturing the twelve months of the year) can be included in equation (2) as follows:

$\Delta \operatorname{Ln}\left(P_{t}\right)=\sum_{i=1}^{12} \beta_{i} M_{i t}+\sum_{i=1}^{k} \eta_{i} \Delta \operatorname{Ln}\left(P_{t-i}\right)+\varepsilon_{t}$

Then, the resulting $\beta_{1}, \beta_{2}, \ldots, \beta_{12}$ coefficients would be equal to $\alpha, \alpha+\tilde{\beta}_{2}, \alpha+\tilde{\beta}_{3}, \ldots, \alpha+\tilde{\beta}_{12}$ in equation (1), respectively. In equation (2), each $\beta_{i}$ directly indicates the expected average return in the corresponding month of the year during the sample period, whereas $\tilde{\beta}_{2}$ shows by how much the average return in a given month differs from the expected average return in January (as the benchmark or reference month). The $\beta$ coefficient in equation (2) can undergo significant structural shifts over time. To address this problem, this study proposes equation (3).

$\Delta \operatorname{Ln}\left(P_{t}\right)=\left[\sum_{i=1}^{12} \beta_{i}^{j} M_{i t}+\sum_{i=1}^{k} \eta_{i}^{j} \Delta \operatorname{Ln}\left(P_{t-i}\right)\right] 1\left(T_{t}<T_{b}\right)+\left[\sum_{i=1}^{12} \beta_{i}^{j} M_{i t}+\sum_{i=1}^{k} \eta_{i}^{j} \Delta \operatorname{Ln}\left(P_{t-i}\right)\right] 1\left(T_{t} \geq T_{b}\right)+\varepsilon_{t}$

where $\beta_{i}^{j}$ and $\eta_{i}^{j}$ are the respective estimated coefficients for the month and $i^{t h}$-lagged dependent variable before $(j=1)$ and after $(j=2)$ an endogenously determined break date $\left(T_{b}\right), 1(\cdot)$ 
is an indicator function, which equals one if the condition in parentheses is met and zero otherwise, and all other variables are as previously defined.

The $k$-order autoregressive term is added to ensure that $\varepsilon_{t}$ is well behaved. The Schwarz information criterion (SIC) determines the optimal lag length. The interpretation of the coefficients is straightforward. For example, if $\beta_{6}$ is greater than other eleven $\beta$ coefficients, it is concluded that the average return in June is more than those of other months during the sample period. Equation (3) in a more compact form is as follows:

$$
\Delta \operatorname{Ln}\left(P_{t}\right)=\sum_{j=1}^{2} 1_{j}\left(T_{t}, T_{b}\right) \cdot\left[\sum_{i=1}^{12} \beta_{i}^{j} M_{i t}+\sum_{i=1}^{k} \eta_{i}^{j} \Delta \operatorname{Ln}\left(P_{t-1}\right)\right]+\varepsilon_{t}
$$

This paper corrects for unknown forms of heteroscedasticity and/or autocorrelation using Newey-West estimators of the heteroscedasticity and autocorrelation consistent covariance (HAC) matrix. In equations (3)-(4), $T_{t}$ serves as a threshold variable. To estimate $T_{b}$ (i.e. the break date), it is standard practice to conduct a grid search for all possible dates within the sample. For each possible date in the grid, equation (4) is estimated after defining the indicator function. In order to have at least 40 observations at each end of the sample period $(j=1,2)$, the trimming percentage is set at $20 \%$. Within the specified lower and upper dates for $T_{t}$ (i.e. $T^{l}$ and $T^{u}$ ), the residual sum of squares (RSS) is minimised with respect to the three sets of parameters:

$$
S\left(\beta_{i}^{j}, \eta_{i}^{j}, T_{b}\right)=\sum_{t=1}^{T}\left\{\Delta \operatorname{Ln}\left(P_{t}\right)-\sum_{j=1}^{2} 1_{j}\left(T_{t}, T_{b}\right) \cdot\left[\sum_{i=1}^{12} \beta_{i}^{j} M_{i t}+\sum_{i=1}^{k} \eta_{i}^{j} \Delta \operatorname{Ln}\left(P_{t-1}\right)\right]\right\}^{2}
$$

For all possible dates within the trimming region, this paper estimates the RSS in an iterative manner. The date $T_{b}$ (i.e. the threshold parameter) yields the lowest RSS. That is:

$$
\begin{gathered}
\hat{T}_{b}=\underset{\gamma \in\left[T^{l}, T^{u}\right]}{\arg \min } \operatorname{RSS}\left(T_{b}\right) \\
x^{\prime}
\end{gathered}
$$


After determining $\hat{T}_{b}$, the whole sample is divided into two subsamples and apply a conventional estimation method to each. To justify the relevance of our proposed model, this paper also conducts the BAI and PERRON (2003) test to compare the threshold autoregressive model (equations 3-4) with a standard non-threshold linear model. Given limited observations, this study only allows two regimes to ensure both subsamples have more than 40 observations.

\section{DATA}

This paper obtains monthly house and apartment prices for Australia's eight capital cities from SIRCA's (2016) CoreLogic RP online database. As of February 2016, the RP data were available for the period $1995 \mathrm{~m} 12-2015 \mathrm{~m} 11$, providing us with 240 monthly observations for six of the eight capital cities (see also notes below Table 1). In comparison, the alternative ABS dataset is available only at a quarterly frequency yielding a much smaller number of observations, thereby preventing the use of breaking regressions, which require an additional $20 \%$ trimming region separating the two split-samples. In terms of comparable studies, RosENTHAL (2006) also used hedonic price indexes, employing data from the Nationwide Building Society mortgage database on UK dwelling transactions. Meanwhile, NGAI and TENREYro (2014) used repeat-sales price indexes created using prices from the Land Registry for England and Wales in the UK and the Federal Housing Finance Agency and Standard and Poor's (S\&P) Case-Shiller price series in the US.

$$
<<\text { TABLE } 1>>
$$

CoreLogic employs a hedonic imputation methodology that has been recognised as being robust at varying levels of disaggregation, across both time and space (see eg. GoH et al., 2012). One may, nevertheless, be still concerned about the hedonic imputation methodology applied by CoreLogic. To address these concerns the quarterly RP data are compared with quarterly data 
from the more established ABS series. The ABS (2015, Cat. 6416, Table 8) published 'established house price indices' (not separate house and apartment prices) for all capital cities from June 1986 to June 2005. However, after September 2005, the ABS (2015, Cat 6416, Table 2) adopted a different methodology and published and backdated established house price indices only from March 2002.

Combining both series (ABS, 2015a, Tables 2 and 8) yields 118 quarterly observations for house prices only, spanning the period from June 1986 to September 2015 at the time of writing. In order to compare the RP data with the more established ABS dataset, first the RP data are converted from monthly to quarterly frequency. The graphs in Appendix A1 display quarterly house price growth rates (log differences) in all eight capital cities using both ABS and RP data for the available common sample period (1996q1-2015q3, $n=79)$. As shown by the individual time plots, there is a strong positive correlation between the series. However, the RP data appears noisier, particularly for the smaller cities of Darwin and Hobart.

To assess whether imputation plays more of a role than calculation in the RP data, this study tests the equality of means and variances of the $\Delta \operatorname{Ln}\left(P_{t}\right)$ series for both the ABS and RP quarterly data (1995q1-2015q3). The reported $t$ and Anova $F$ tests as well as the Levene and BrownForsythe $F$ tests in Appendix A2 indicate that the null hypotheses (equality of means and variances) cannot be rejected at the $5 \%$ or even $10 \%$ levels. It is concluded that both the ABS and RP data are comparable, although in terms of variance equality, Darwin a borderline case (see the corresponding $p$-value $=0.11$ in Appendix T1). This finding is consistent with our observation in Appendix F1. ${ }^{3}$

CoreLogic RP data control for changes in housing quality, with the hedonic price index adjusting for observed housing characteristics and the repeat-sales index measuring the average 
price changes in repeat sales of the same properties. By considering a wide range of property attributes for a large number of dwellings, the approach underlying our chosen database reduces the bias that exists in other house price indicators for Australia, such as with median or repeatsales prices. Moreover, unlike the price indices available from either the ABS or the REIA, which are both only quarterly, our price data are monthly. This should yield a more accurate assessment of seasonality in the housing market.

However, the data employed have some limitations. A major problem is that one cannot obtain detailed information on the number of transactions used to compile the index. Along with price, volume represents one of the most basic and important indicators of market activity. For example, increasing volume can be an indication that prices will increase in the future. Simultaneous increases in prices and volume are an even more bullish (positive or buy) signal. On the other hand, decreasing volume is an indication that prices may fall in the future. A combination of falling prices and volume is then a bearish (negative or sell) signal for future prices.

For both house and apartment return series, this paper formally tested the following equality of the standard deviation $(\sigma)$ before (B) and after (A) the 2008 GFC. The results are given in Appendix T2:

$H_{0}: \sigma^{B G F C}=\sigma^{A G F C}$ vs. $H_{1}: \sigma^{B G F C}<\sigma^{A G F C}$

The test results suggest that the above null hypothesis versus the alternative is rejected at the $2 \%$ level of significance or better for all capital cities with the exception of Canberra. It is concluded that the growth rates for house and apartment prices, i.e. $\Delta \operatorname{Ln}\left(P_{t}\right)$, are more volatile in the post- than pre-2008 GFC era. Figure 1 plots the monthly growth rates of house and apartment 
prices for each capital city, from which it is also obvious that the volatility of property returns has increased markedly from late 2007 onwards for almost all cities.

$$
<<\text { FIGURE } 1>>
$$

Table 1 presents a summary of descriptive statistics of the monthly price changes for the eight capital city house and apartment markets. The largest mean monthly house price growth rates (log differences expressed in percentages) pre-GFC was in Perth $(0.938 \%)$ and post-GFC was in Sydney $(0.550 \%)$. For apartments, the largest monthly mean returns pre-GFC were in Hobart $(0.880 \%)$ and post-GFC was in Sydney $(0.495 \%)$. Hobart and Darwin are the most volatile markets for apartments and houses respectively both before and after the GFC.

The results of the Zivot and Andrews (1992) unit root test are shown in Appendix T3, in which the null hypothesis of nonstationary is tested against the alternative of no unit root for both $\operatorname{Ln}\left(p_{t}\right)$ and $\Delta \operatorname{Ln}\left(p_{t}\right)$. Based on these results, $\operatorname{Ln}\left(p_{t}\right)$ and $\Delta \operatorname{Ln}\left(p_{t}\right)$ are I(1) and I(0), respectively. Similar results are obtained when the augmented Dickey Fuller test is applied (results not reported).

$$
<<\text { TABLE } 2>>
$$

\section{RESULTS AND DISCUSSION}

Table 2 presents the coefficients, standard errors, and $p$-values of the seasonal and other parameters outlined in our methodology. This paper endogenously tested separate break dates for each of the 16 models and provided the estimated parameters in the period before, and after, the corresponding threshold. According to the BAI and PERRON (2003) test results (available upon request), the null of no structural break is rejected against one structural break at the 0.05 level for all 16 equations. The detected break dates vary across both the capital cities and the house and apartment markets, but are closely clustered, as you would expect from a single national 
housing market. For most markets, the break dates occurred in 2011. There is rather more variation in the break dates in the apartment markets, with the break date in the Darwin apartment market occurring in 2012 and Perth in 2010.

In Table 2, for each capital city, the estimated results for houses and apartments are provided for the first period (from December 1995 to the break date) above the line and those for the second period (after the break date until November 2015) under the line. Although all 12 seasonal dummy variables are included in each of the 16 models, only the statistically significant coefficients are generally displayed. The exception is that if $\beta_{i}^{j}$ is statistically significant at the 0.05 level for a given period, the corresponding coefficient for the other period is also reported, irrespective of its significance. To illustrate, above the line in the first period, the coefficient for $\beta_{3}^{1}$ in March for Adelaide house returns when $T_{t}<2011 \mathrm{M} 07$, is 0.0133 , which is statistically significant at the 0.05 level. Thus, while this same coefficient (i.e. $\beta_{3}^{2}=-0.0041$ ) is insignificant when $T_{t} \geq 2011 \mathrm{M} 07$, the results are reported. But, if $\beta_{3}^{1}$ was insignificant, $\beta_{3}^{2}$ would not have been reported.

While simple in terms of the explanatory variables included, all models appear to perform adequately in explaining price growth rates in each of the eight capital cities. In terms of adjusted $R^{2}$, the Melbourne and Sydney models perform best, explaining about $69.5 \%$ and $75.7 \%$ of the variation in house price changes and $53.5 \%$ and $49.6 \%$ of monthly apartment price changes, respectively. The worst performing models are for Canberra and Darwin, where the respective proportion of variance explained for houses and apartments is only $45.2 \%$ and $26.3 \%$ for the former and $34.8 \%$ and $15.9 \%$ in the latter. 
It is also important to evaluate the out-of-sample forecasting accuracy of the estimated equations in Table 2. To this end, this study forecasts the monthly price growth for 12-months outside the estimation sample. In other words, instead of the final estimation period $1995 \mathrm{~m} 12$ $2015 \mathrm{~m} 11$, the shortened period $1995 \mathrm{~m} 12-2014 \mathrm{~m} 11$ is used to re-estimate and generate the outof-sample dynamic forecasts for $2014 \mathrm{~m} 11-2015 \mathrm{~m} 11$. The pair-wise comparisons between actual and out-of-sample forecasts displayed in Appendix F2 together with the two measures of forecasting accuracy (i.e. RMSE=Root Mean Squared Error and MAE=Mean Absolute Error) in Appendix T4 suggest that the estimated equations perform reasonably well. Although this study does not seek to forecast all seesaw changes in property returns, the estimated equations, appearing in the lower part of Table 2, are capable of capturing key turning points in return price series.

In more recent times (i.e. $T_{t} \geq \hat{T}_{b}$ ), there has been a systematic decrease in the autoregressive coefficients, making future return changes less path dependent and more difficult to predict. As shown in Table 2, for all cities the coefficient sum associated with the lagged dependent variable (i.e. $\sum_{i=1}^{k} \eta_{i}^{j}$ ) was positive and well below unity in the pre-GFC period. However, in the post-GFC the same coefficient sum was negative and in absolute value within unity circle for all cities (except Sydney). One should note that when $0<\sum_{i=1}^{k} \eta_{i}^{j}<-1$, the estimated equations produce cyclical movements which appear to be consistent with rising volatility in the post-2008 GFC as discussed earlier. This means that monthly property price returns have exhibited oscillatory behaviour since 2008. Even in the case of Sydney, although the corresponding sums are positive, they have become less-path dependent. These coefficient sums for house and apartment returns fell from 0.89 and 0.60 in the pre-GFC period to 0.59 and 0.15 in the post-GFC period, 
respectively (see Table 2). Overall, one can argue that property price returns in the short run are subject to less inertia and/or become highly volatile, noisy and very difficult to predict. This finding is consistent with the increasing volatility of residential housing returns in the post-2007 era (see Figure 1).

Now consider the seasonal effects in the first period for houses, which for most markets is the period before late 2011. Table 3 summarizes the month-of-the-year effect results for houses and apartments across the eight capital cities. In terms of economic magnitude, in the first period, the positive seasonal effect (and the opportunity for largest abnormal gains/losses by sellers/buyers) for houses is most significant for Darwin in March (1.49\%) and Sydney in February $(2.11 \%)$ and for apartments is most significant for Canberra in October $(1.45 \%)$ and for Hobart in June $(3.06 \%)$.

$$
<<\text { TABLE } 3>>
$$

The seasonal effects for both houses and apartments in the second period (i.e. more recent years) are greater than the first period. For example, in the second period, the July effect in the Melbourne house market (3.73\%) was three times greater than the January effect $(1.05 \%)$ in the first period. Similarly, in the apartment market in Sydney, the June effect (3.04\%) in the second period was three times the February effect $(1.01 \%)$ in the first period. This result, at least in part, reflects the investment boom in property in the second period, which, in the case of Melbourne and Sydney, links to the timing of the seasonal effect at, or immediately after, the end of the financial year. The calendar effects in Table 3 translate to significant monetary values. For example, the largest positive effects for both Melbourne and Sydney house returns in the second period are $3.73 \%$ and $2.27 \%$, respectively. Based on median prices in November 2015, this 
equates to an abnormal gain (loss) for house sellers (buyers) of $\$ 29,670$ in Melbourne and up to $\$ 22,750$ in Sydney.

In the first period, the largest positive effect occurs in summer (December, January, or February) for half of the cities for both houses and apartments. In the second period, there is less evidence of the most expensive month being in summer. For houses, the most expensive month is in summer in three cities for houses and two cities for apartments. In the second period, there is a hot season for selling in Brisbane, Hobart, and Perth for houses and Darwin and Hobart for apartments.

However, across both periods, there is rather less evidence of the cheapest months to buy falling in the winter months (June, July, or August). For houses, the cheapest month to purchase is in winter in Canberra in the first period, and Adelaide and Darwin in the second period. For apartments, the cheapest month to purchase is in winter in Adelaide, Hobart, and Perth in the first period and Canberra in the second period. Taking a broader view of what precisely constitutes hot and cold seasons, and treating the spring and summer months as the hot season, and autumn and winter as the cold season, there is slightly more evidence of cold and hot seasonal effects across the two periods. In the first period, the most expensive month to purchase falls in summer or spring for five of the eight cities for houses and three-quarters of the cities for apartments. In the second period, the cheapest month to purchase falls in autumn or winter for five of the eight cities for houses and half of the cities for apartments.

The high and low return months lie adjacent (e.g. December and January) or within one-two months of each other (e.g. December and February) in several instances. The lowest priced month follows the highest priced month in the first period for houses in Hobart and for apartments in Adelaide, Canberra, and Hobart, while in the second period this holds for houses in 
Perth. The lowest priced month is followed by the highest priced month in the first period for houses in Brisbane, Melbourne and Sydney and for apartments in Sydney, while in the second period this occurs in Melbourne and Sydney for houses and Melbourne and Canberra for apartments.

Cases where the lowest priced month follows (within one-two months) the highest priced month is consistent with the overreaction hypothesis (DE BONDT and THALER, 1985). This states that investors tend to overweight new information and underweight past information, generating a sudden rise in house prices, followed by a sharp correction shortly after when they realize the reality of the situation and prices start to fall. This reflects biased self-attribution in which investor overconfidence enhances private price signals and public information represents noise (DANIEL et al., 1998). Conversely, where the highest priced month follows the lowest priced month, this is consistent with an under-reaction hypothesis. Investors initially underreact to news given behavioural biases (HONG and STEIN, 1999) or loss aversion (FrAZZINI, 2006), but then seek higher returns pushing up prices shortly thereafter.

There is most support for the under-reaction hypothesis for houses and the overreaction hypothesis for apartments in the first period (both for three of the eight capital cities). In terms of differences across locales, most support for the under-reaction hypothesis is in the larger markets (Melbourne, Sydney, and Brisbane), while most support for the over-reaction hypothesis is in the smaller markets (Adelaide, Canberra, Hobart, and Perth). The latter finding is consistent with the prediction of Hong and STEIN (1999) that over-reaction results from short-term speculators seeking to exploit short-term price returns in thin markets in which information is relatively scarce. 
Other factors are also possibly at play. For houses in seven of the eight cities in the first period and half of the cities in the second period, and for apartments in three of the eight cities in both periods, the highest priced month is in the first three months of the year. These months in Australia broadly align with the start of the new school year, the commencement of public service contracts (especially in education), and the ending of the summer holiday period.

Likewise, in Adelaide, Hobart, Melbourne, Perth, and Sydney, there is some evidence of clustering in the apartment market around the end of the financial year and at the beginning of the next financial year. In Australia, many apartments are investment properties. As such, the market for apartments is likely to be less sensitive to the logistics of moving house in time for commencement of the new school year or taking up a new job. Moreover, investors can minimize the amount of capital gains tax (CGT), payable on an investment property by selling it shortly before June 30 . If a property sells in mid-June, for example, but the sale does not settle until July or August, investors will not have to pay the CGT on the capital growth achieved on their property for 12 months or more. At the same time, investors are in a position to increase and maximize deductions on rental property in the financial year in which it sells.

\section{CONCLUSION}

This paper examined regional variations in seasonality in the form of a month-of-the-year effect in both house and apartment price returns across eight Australian capital cities over the period December 1995 to November 2015. This paper found strong evidence of a structural break in seasonality broadly corresponding to the 2008 GFC. Strong monthly seasonal effects are then identified in all markets, which varied across both capital city/region and property type. The estimated threshold autoregressive models tended to perform better (in terms of explanatory power) for house returns than apartment returns, particularly in the larger capital cities. 
The significance and general consistency of the monthly seasonal effects lend some support to the belief of industry practitioners and house buyers and sellers that some months represent a 'hot season', in which returns are systematically higher than what they otherwise would be, while others are suggestive of a 'cold season' with correspondingly lower returns. Equally, there is some evidence consistent with the overreaction and underreaction hypotheses. The existence of regional seasonality presents a good opportunity for sellers and buyers to make systematically higher abnormal gains than they would otherwise, up to $6 \%$ on a month-on-month basis. In general, this paper does not find clear systematic differences in regional seasonality in house price returns between those capital cities located in temperate climates, and Brisbane and Darwin, located in sub-tropical and tropical climates, respectively.

This study also found that the Australian market has experienced significant change in the 20-year sample period. In the two largest markets of Melbourne and Sydney, there is evidence that the investment boom has influenced the seasonal effect in the second period with the monthof-the-year effect now coinciding with the end of the financial year. In addition, house and apartment price returns were both noticeably more volatile in the most recent regime. Interestingly, while volatility has been on the rise, the highest negative and positive month-ofthe-year seasonal effects have also increased in magnitude. Problematically for buyers (sellers) seeking to predict the best month in which to purchase (sell), the best and poorest selling months implied by our analysis have moved, whereas in the earlier period prior to the GFC they were much more stable.

Therefore, while it may be possible to make abnormal gains with knowledge of these seasonal effects, there is no guarantee that they will not experience further change in the future. The presence of seasonal effects represents a significant challenge to the notion that residential 
housing markets are efficient. Moreover, these seasonal effects may lie at the heart of the ongoing volatility in housing returns with short-term local market conditions and expectations primarily driving house price changes, rather than any longer-term broader fundamentals. Such an outcome would be consistent with the existence of concentrated housing markets in regional areas that are geographically far apart.

\section{NOTES}

1. In 2015, Australia's population was 23.1 million people, compared with 64.1 million in the UK and 320 million in the US.

2. For a concise discussion of alternative methods to measure seasonality, see COSHALL et al. (2015).Similarly, the REI reports quarterly median established house prices from 1980q1, generating 142 observations. However, apartment prices have only become available since 1998q3, providing only 69 observations. Thus there are insufficient observations for running breaking regressions. 


\section{REFERENCES}

AKIMOV A. STEVENSON S. and YOUNG J. (2015) Synchronisation and commonalities in metropolitan housing market cycles, Urban Studies 52, 1685-1682.

AUSTRALIAN BUREAU OF STATISTICS (2015) Residential Property Price Indexes: Eight Capital Cities. Australian Government, Canberra.

BAI J. and PERRON P. (2003) Computation and analysis of multiple structural change models, Journal of Applied Econometrics 18, 1-22.

CASE K. and SHILLER R. (1989) The efficiency of the market for single-family homes, American Economic Review 79, 125-137.

COSHALL J., CHARLESWORTH R. and PAGE S. J. (2015) Seasonality of overseas tourism demand in Scotland: a regional analysis. Regional Studies 49, 1603-1620.

COLEBATCH T. (2010) Caught in the cogs of the tax regime, The Age, Melbourne, March 30.

COLWELL P. and PARK H. (1990) Seasonality and size effects - the case of real-estate-related investment, Journal of Real Estate Finance and Economics 3, 251-259.

COSTELlO G. (2001) Seasonal influences in Australian housing markets, Pacific Rim Property Research Journal 7, 47-60.

CROUCHER S. (2014) UK House Prices: Is Housing Market Suffering Seasonal Slowdown or Fundamental Shift? International Business Times, http://www.ibtimes.co.uk/ (accessed October 2015).

DANIEL K., HIRSHLEIFER D. and SUBRAHMANYAM A. (1998) Investor psychology and security market under-and overreactions. Journal of Finance 53, 1839-1885.

DE BONDT W. and THALER R. 1985. Does the stock market overreact? Journal of Finance 40, 793-805.

DEMOGRAPHIA (2015) International Housing Affordability Survey, $11^{\text {th }}$ ed., http://www.demographia.com/ (accessed August 11, 2015).

GOH Y. M., COSTELLO G. and SCHWANN G. (2012) The accuracy and robustness of real estate price index methods, Housing Studies 27, 643-666.

HONG H. and STEIN J. C. (1999) A unified theory of underreaction, momentum trading, and overreaction in asset markets, Journal of Finance 54, 2143-2184.

HUI E. C. M., WRIGHT J. A., and YAM S. C. P. (2013) Calendar effects and real estate securities, The Journal of Real Estate Finance and Economics 49, 91-115.

KARAMUJIC H. (2012) Modelling seasonality in Australian building approvals, Australasian Journal of Construction Economics and Building 12, 26-36

KUETHE T. H. and PEDE V. O. (2011) Regional housing price cycles: a spatio-temporal analysis using US state-level data, Regional Studies 45, 563-574 
LERBS O. W. and OBERST C. A. (2014) Explaining the spatial variation in homeownership rates: results for German regions, Regional Studies 48, 844-865

NGAI L. R. and TENREYRO S. (2014) Hot and cold seasons in the housing market, American Economic Review 104, 3991-4026.

PIAZZESI M., SCHNEIDER M. and TUZEL S. (2007) Housing, consumption and asset pricing, Journal of Financial Economics 83, 531-569.

ROSENTHAL L. (2006), Efficiency and seasonality in the UK housing market, 1991-2001, Oxford Bulletin of Economics and Statistics 68, 289-317.

SIRCA (2016) CoreLogic RP Aggregate Database, http://www.sirca.org.au/ (accessed 8 February 2016).

VALADKHANI A., SMYTH R., and WORTHINGTON A. (2016) self-exciting effects of house prices on unit prices in Australian capital cities, Urban Studies, in press, DOI: $10.1177 / 0042098016643476$

ZIVOT E. and ANDREWS K. (1992) Further evidence on the great crash, the oil price shock, and the unit root hypothesis, Journal of Business and Economic Statistics 10, 251-270. 
Table 1. Descriptive statistics for monthly price growth before and after GFC

\begin{tabular}{|c|c|c|c|c|c|c|}
\hline \multirow[b]{2}{*}{ City } & \multicolumn{3}{|c|}{ Pre-GFC (1995m12-2007m12 $(n=144)$} & \multicolumn{3}{|c|}{ Post GFC $(1995 \mathrm{~m} 12-2007 \mathrm{~m} 12(n=95)$} \\
\hline & $\begin{array}{c}\text { Mean } \\
(\%)\end{array}$ & $\begin{array}{c}\text { Std. } \\
\text { Dev. }(\%)\end{array}$ & $\begin{array}{l}\text { CV } \\
(\%)\end{array}$ & $\begin{array}{c}\text { Mean } \\
(\%)\end{array}$ & $\begin{array}{c}\text { Std. } \\
\text { Dev. }(\%)\end{array}$ & $\begin{array}{l}\mathrm{CV} \\
(\%) \\
\end{array}$ \\
\hline \multicolumn{7}{|l|}{ Adelaide } \\
\hline Houses & 0.799 & 0.827 & 104 & 0.158 & 1.147 & 726 \\
\hline Apartments & 0.735 & 0.912 & 124 & 0.052 & 2.064 & 3953 \\
\hline \multicolumn{7}{|l|}{ Brisbane: } \\
\hline Houses & 0.852 & 0.891 & 105 & 0.096 & 1.116 & 1158 \\
\hline Apartments & 0.618 & 0.970 & 157 & 0.076 & 1.494 & 1968 \\
\hline \multicolumn{7}{|l|}{ Canberra: } \\
\hline Houses & 0.764 & 1.148 & 150 & 0.209 & 1.185 & 567 \\
\hline Apartments & 0.650 & 1.377 & 212 & 0.097 & 1.514 & 1566 \\
\hline \multicolumn{7}{|l|}{ Darwin: } \\
\hline Houses & 0.763 & 1.205 & 158 & 0.246 & 2.432 & 990 \\
\hline Apartments & 0.874 & 1.456 & 166 & 0.141 & 3.243 & 2302 \\
\hline \multicolumn{7}{|l|}{ Hobart: } \\
\hline Houses & 0.776 & 1.194 & 154 & -0.066 & 1.999 & -3036 \\
\hline Apartments & 0.880 & 2.560 & 291 & 0.024 & 4.046 & 16948 \\
\hline \multicolumn{7}{|l|}{ Melbourne: } \\
\hline Houses & 0.877 & 0.769 & 88 & 0.449 & 1.760 & 392 \\
\hline Apartments & 0.731 & 0.757 & 104 & 0.335 & 1.527 & 455 \\
\hline \multicolumn{7}{|l|}{ Perth: } \\
\hline Houses & 0.938 & 0.865 & 92 & 0.031 & 1.206 & 3951 \\
\hline Apartments & 0.804 & 0.845 & 105 & 0.079 & 1.730 & 2202 \\
\hline \multicolumn{7}{|l|}{ Sydney: } \\
\hline Houses & 0.688 & 1.005 & 146 & 0.550 & 1.252 & 227 \\
\hline Apartments & 0.533 & 0.672 & 126 & 0.495 & 1.152 & 233 \\
\hline
\end{tabular}

Notes: In the pre-GFC period there were 144 observations available for both house and apartment prices in Darwin and 123 observations available for apartment prices in Hobart. $\mathrm{CV}=$ coefficient of variation defined as standard deviation divided by mean multiplied by 100 . 
Table 2 Estimated month-of-the-year effects $\Delta \operatorname{Ln}\left(P_{t}\right)=\sum_{j=1}^{2} 1_{j}\left(T_{t}, T_{b}\right) \cdot\left[\sum_{i=1}^{12} \beta_{i}^{j} M_{i t}+\sum_{i=1}^{k} \eta_{i}^{j} \Delta \operatorname{Ln}\left(P_{t-1}\right)\right]+\varepsilon_{t}$

\begin{tabular}{|c|c|c|c|c|c|c|c|c|c|c|c|c|c|c|c|c|}
\hline \multirow{4}{*}{ Description } & \multicolumn{4}{|c|}{ Adelaide } & \multicolumn{4}{|c|}{ Brisbane } & \multicolumn{4}{|c|}{ Canberra } & \multicolumn{4}{|c|}{ Darwin } \\
\hline & \multirow{2}{*}{\multicolumn{2}{|c|}{$\begin{array}{c}\text { Houses } \\
T_{t}<2011 \mathrm{M} 07 \\
(n=185) \\
\end{array}$}} & \multirow{2}{*}{\multicolumn{2}{|c|}{$\begin{array}{c}\text { Apartments } \\
T_{t}<2011 \mathrm{M} 03 \\
(n=181) \\
\end{array}$}} & \multicolumn{2}{|c|}{ Houses } & \multicolumn{2}{|c|}{ Apartments } & \multicolumn{2}{|c|}{ Houses } & \multicolumn{2}{|c|}{ Apartments } & \multicolumn{2}{|c|}{ Houses } & \multicolumn{2}{|c|}{ Apartments } \\
\hline & & & & & \multicolumn{2}{|c|}{$T_{t}<2008 \mathrm{M} 12(n=155)$} & \multicolumn{2}{|c|}{$\begin{array}{c}T_{t}<2009 \mathrm{M} 08 \\
\quad(n=162) \\
\end{array}$} & \multicolumn{2}{|c|}{$\begin{array}{c}T_{t}<2010 \mathrm{M} 03 \\
(n=168)\end{array}$} & \multicolumn{2}{|c|}{$\begin{array}{c}T_{t}<2010 \mathrm{M} 07 \\
(n=173)\end{array}$} & \multicolumn{2}{|c|}{$\begin{array}{c}T_{t}<2011 \mathrm{M} 11 \\
(n=149)\end{array}$} & \multicolumn{2}{|c|}{$\begin{array}{c}T_{t}<2011 \mathrm{M} 12 \\
(n=150)\end{array}$} \\
\hline & Coeff. & $p$-value & Coeff. & $p$-value & Coeff. & $p$-value & Coeff. & $p$-value & Coeff. & $p$-value & Coeff. & $p$-value & Coeff. & $p$-value & Coeff. & $p$-value \\
\hline $\begin{array}{l}\text { January } \\
\text { February }\end{array}$ & -0.0055 & 0.00 & 0.0000 & 0.99 & 0.0051 & 0.00 & $\begin{array}{l}0.0056 \\
0.0113\end{array}$ & $\begin{array}{l}0.04 \\
0.00\end{array}$ & 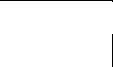 & 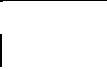 & 0.00959 & 0.00 & -0.0007 & 0.79 & & \\
\hline March & 0.0133 & 0.00 & 0.0070 & 0.00 & & & 0.0047 & 0.02 & 0.0103 & 0.00 & & & 0.0149 & 0.00 & 0.0107 & 0.01 \\
\hline April & 0.0007 & 0.66 & 0.0140 & 0.00 & & & -0.0058 & 0.03 & & & 0.00930 & 0.00 & 0.0060 & 0.19 & & \\
\hline May & -0.0029 & 0.02 & & & 0.0005 & 0.51 & 0.0029 & 0.12 & & & & & -0.0153 & 0.00 & & \\
\hline June & -0.0020 & 0.04 & -0.0053 & 0.09 & 0.0019 & 0.01 & 0.0080 & 0.00 & -0.0053 & 0.00 & 0.00403 & 0.18 & 0.0078 & 0.01 & & \\
\hline July & -0.0045 & 0.00 & & & 0.0034 & 0.00 & & & -0.0010 & 0.74 & & & 0.0114 & 0.03 & & \\
\hline August & 0.0058 & 0.00 & 0.0077 & 0.00 & -0.0016 & 0.01 & 0.0001 & 0.97 & & & 0.00132 & 0.70 & 0.0066 & 0.09 & 0.0057 & 0.00 \\
\hline September & 0.0094 & 0.00 & 0.0061 & 0.00 & 0.0009 & 0.19 & 0.0036 & 0.08 & 0.0112 & 0.00 & & & & & -0.0012 & 0.69 \\
\hline October & -0.0062 & 0.00 & 0.0030 & 0.13 & & & 0.0078 & 0.00 & & & 0.01448 & 0.00 & & & & \\
\hline Noven & 0.0063 & 0.00 & & & & & -0.0102 & 0.00 & & & -0.00779 & 0.01 & & & & \\
\hline December & & & 0.0002 & 0.92 & -0.0019 & 0.00 & -0.0039 & 0.01 & -0.0036 & 0.10 & -0.00485 & 0.04 & 0.0065 & 0.03 & 0.0116 & 0.03 \\
\hline$\Delta \operatorname{Ln}\left(P_{t-1}\right)$ & 0.4445 & 0.00 & 0.2819 & 0.00 & 0.9421 & 0.00 & 0.2141 & 0.00 & 0.1702 & 0.01 & 0.13697 & 0.11 & 0.3663 & 0.00 & 0.2651 & 0.00 \\
\hline$\Delta \operatorname{Ln}\left(P_{t-2}\right)$ & 0.3990 & 0.00 & 0.2730 & 0.00 & & & 0.4400 & 0.00 & 0.4528 & 0.00 & 0.37017 & 0.00 & 0.1217 & 0.37 & 0.0874 & 0.36 \\
\hline \multirow[t]{2}{*}{$\Delta \operatorname{Ln}\left(P_{t-3}\right)$} & & & & & & & & & 0.2367 & 0.00 & & & & & & \\
\hline & \multicolumn{2}{|c|}{$\begin{array}{c}T_{t} \geq 2011 \mathrm{M} 07 \\
(n=52)\end{array}$} & \multicolumn{2}{|c|}{$\begin{array}{c}T_{t} \geq 2011 \mathrm{M} 04 \\
(n=56)\end{array}$} & \multicolumn{2}{|c|}{$\begin{array}{c}T_{t} \geq 2009 \mathrm{M} 01 \\
(n=83)\end{array}$} & $\begin{array}{r}T_{t} \geq 20 \\
(n=\end{array}$ & 9M09 & $\begin{array}{r}T_{t} \geq 20 \\
(n=\end{array}$ & $\begin{array}{l}\text { 10M04 } \\
68)\end{array}$ & $\begin{array}{r}T_{t} \geq 20 \\
(n=6\end{array}$ & $\begin{array}{l}0 \mathrm{M} 8 \\
4)\end{array}$ & $\begin{array}{r}T_{t} \geq 20 \\
(n=\end{array}$ & 11M12 & $\begin{array}{r}T_{t} \geq 20 \\
(n=\end{array}$ & $\begin{array}{l}\text { 2M01 } \\
\text { 17) }\end{array}$ \\
\hline $\begin{array}{l}\text { January } \\
\text { February }\end{array}$ & -0.0048 & 0.39 & 0.0156 & 0.04 & 0.0078 & 0.01 & $\begin{array}{c}0.0000 \\
-0.0013\end{array}$ & $\begin{array}{l}1.00 \\
0.78\end{array}$ & & & 0.00380 & 0.71 & -0.0239 & 0.00 & & \\
\hline March & -0.0041 & 0.52 & 0.0187 & 0.00 & & & -0.0006 & 0.91 & 0.0097 & 0.12 & & & 0.0334 & 0.00 & -0.0193 & 0.00 \\
\hline April & 0.0217 & 0.00 & -0.0045 & 0.31 & & & -0.0008 & 0.90 & & & -0.01190 & 0.09 & 0.0265 & 0.00 & & \\
\hline May & -0.0029 & 0.54 & & & -0.0061 & 0.02 & -0.0120 & 0.00 & & & & & -0.0036 & 0.74 & & \\
\hline Jun & 0.0063 & 0.06 & -0.0217 & 0.00 & 0.0050 & 0.07 & 0.0027 & 0.64 & 0.0095 & 0.01 & -0.01248 & 0.01 & -0.0301 & 0.00 & & \\
\hline July & -0.0183 & 0.00 & & & -0.0025 & 0.57 & & & 0.0093 & 0.01 & & & 0.0176 & 0.21 & & \\
\hline & 0.0087 & 0.03 & 0.0134 & 0.14 & 0.0024 & 0.50 & 0.0073 & 0.01 & & & 0.00930 & 0.01 & 0.0076 & 0.48 & 0.0102 & 0.50 \\
\hline Septen & 0.0045 & 0.33 & 0.0069 & 0.64 & 0.0060 & 0.04 & 0.0042 & 0.30 & 0.0040 & 0.28 & & & & & -0.0376 & 0.08 \\
\hline October & 0.0018 & 0.65 & 0.0017 & 0.86 & & & 0.0058 & 0.05 & & & 0.00372 & 0.41 & & & & \\
\hline November & 0.0076 & 0.03 & & & & & 0.0071 & 0.39 & & & -0.01055 & 0.02 & & & & \\
\hline December & & & -0.0228 & 0.01 & 0.0027 & 0.63 & -0.0110 & 0.01 & -0.0070 & 0.08 & -0.00672 & 0.22 & -0.0046 & 0.57 & 0.0132 & 0.55 \\
\hline$\Delta \operatorname{Ln}\left(P_{t-1}\right)$ & -0.2597 & 0.04 & -0.4946 & 0.00 & -0.2234 & 0.06 & -0.4710 & 0.00 & -0.1375 & 0.21 & -0.27482 & 0.02 & -0.4497 & 0.00 & -0.3747 & 0.02 \\
\hline $\begin{array}{l}\Delta \operatorname{Ln}\left(P_{t-2}\right) \\
\Delta \operatorname{Ln}\left(P_{t-3}\right)\end{array}$ & -0.4003 & 0.00 & -0.2401 & 0.24 & & & -0.1361 & 0.15 & $\begin{array}{l}-0.1570 \\
-0.2621\end{array}$ & $\begin{array}{l}0.16 \\
0.03\end{array}$ & -0.43841 & 0.00 & -0.2954 & 0.01 & -0.3659 & 0.00 \\
\hline $\begin{array}{l}\Delta L n\left(P_{t-3}\right) \\
\operatorname{Adj}^{2}\end{array}$ & 0.652 & & 0.355 & & 0.595 & & 0.337 & & 0.452 & 0.00 & 0.263 & & 0.348 & & 0.159 & \\
\hline$D W$ & 1.96 & & 2.18 & & 1.81 & & 2.05 & & 2.01 & & 2.16 & & 1.99 & & 2.08 & \\
\hline$S I C$ & -6.951 & & -5.600 & & -6.873 & & -5.877 & & -6.361 & & -5.599 & & -5.082 & & -4.458 & \\
\hline
\end{tabular}

Note: The standard errors of the coefficients (and the resulting $p$-values) were computed using the Newey-West covariance matrix. 
Table 2. Estimated month-of-the-year effects (continued) $\Delta \operatorname{Ln}\left(P_{t}\right)=\sum_{j=1}^{2} 1_{j}\left(T_{t}, T_{b}\right) \cdot\left[\sum_{i=1}^{12} \beta_{i}^{j} M_{i i}+\sum_{i=1}^{k} \eta_{i}^{j} \Delta L n\left(P_{t-i}\right)\right]+\varepsilon_{t}$

\begin{tabular}{|c|c|c|c|c|c|c|c|c|c|c|c|c|c|c|c|c|}
\hline \multirow{4}{*}{ Description } & \multicolumn{4}{|c|}{ Hobart } & \multicolumn{4}{|c|}{ Melbourne } & \multicolumn{4}{|c|}{ Perth } & \multicolumn{4}{|c|}{ Sydney } \\
\hline & \multirow{2}{*}{\multicolumn{2}{|c|}{$\begin{array}{c}\text { Houses } \\
T_{t}<2010 \mathrm{M} 3 \\
(n=169) \\
\end{array}$}} & \multirow{2}{*}{\multicolumn{2}{|c|}{$\begin{array}{c}\text { Apartments } \\
T_{t}<2011 \mathrm{M} 11 \\
(n=168) \\
\end{array}$}} & \multirow{2}{*}{\multicolumn{2}{|c|}{$\begin{array}{c}\text { Houses } \\
T_{t}<2011 \mathrm{M} 08 \\
(n=185) \\
\end{array}$}} & \multirow{2}{*}{\multicolumn{2}{|c|}{$\begin{array}{c}\text { Apartments } \\
T_{t}<2011 \mathrm{M} 12 \\
(n=190) \\
\end{array}$}} & \multirow{2}{*}{\multicolumn{2}{|c|}{$\begin{array}{c}\text { Houses } \\
T_{t}<2011 \mathrm{M} 08 \\
(n=186) \\
\end{array}$}} & \multirow{2}{*}{\multicolumn{2}{|c|}{$\begin{array}{c}\text { Apartments } \\
T_{t}<2009 \mathrm{M} 12 \\
n=166)\end{array}$}} & \multirow{2}{*}{\multicolumn{2}{|c|}{$\begin{array}{c}\text { Houses } \\
T_{t}<2011 \mathrm{M} 10 \\
(n=188) \\
\end{array}$}} & \multirow{2}{*}{\multicolumn{2}{|c|}{$\begin{array}{c}\text { Apartments } \\
T_{t}<2011 \mathrm{M} 09 \\
(n=188) \\
\end{array}$}} \\
\hline & & & & & & & & & & & & & & & & \\
\hline & Coeff. & $p$-value & Coeff. & $p$-value & Coeff. & $p$-value & Coeff. & $p$-value & Coeff. & $p$-value & Coeff. & $p$-value & Coeff. & $p$-value & Coeff. & $p$-value \\
\hline January & 0.0082 & 0.00 & & & 0.0105 & 0.00 & 0.0074 & 0.00 & & & & & 0.0172 & 0.00 & 0.0072 & 0.00 \\
\hline February & -0.0050 & 0.01 & 0.0123 & 0.00 & 0.0088 & 0.00 & 0.0102 & 0.00 & -0.0020 & 0.02 & 0.0039 & 0.03 & 0.0211 & 0.00 & 0.0101 & 0.00 \\
\hline March & -0.0005 & 0.86 & 0.0136 & 0.02 & & & 0.0016 & 0.40 & 0.0038 & 0.00 & 0.0022 & 0.35 & -0.0019 & 0.25 & 0.0032 & 0.05 \\
\hline April & & & -0.0199 & 0.00 & -0.0006 & 0.65 & & & & & 0.0025 & 0.07 & -0.0103 & 0.00 & & \\
\hline May & & & -0.0020 & 0.68 & -0.0012 & 0.48 & 0.0050 & 0.00 & & & & & -0.0005 & 0.77 & & \\
\hline June & & & 0.0306 & 0.00 & -0.0013 & 0.38 & & & 0.0028 & 0.00 & & & -0.0043 & 0.00 & 0.0055 & 0.00 \\
\hline July & 0.0040 & 0.02 & -0.0158 & 0.00 & 0.0077 & 0.00 & 0.0065 & 0.00 & & & 0.0007 & 0.59 & 0.0055 & 0.00 & 0.0037 & 0.00 \\
\hline August & 0.0060 & 0.02 & -0.0222 & 0.00 & 0.0010 & 0.31 & 0.0032 & 0.02 & 0.0021 & 0.09 & & & 0.0048 & 0.00 & & \\
\hline September & 0.0004 & 0.85 & 0.0056 & 0.56 & & & -0.0036 & 0.06 & & & & & & & -0.0018 & 0.13 \\
\hline October & -0.0017 & 0.27 & 0.0052 & 0.31 & & & 0.0042 & 0.00 & & & & & -0.0027 & 0.02 & 0.0019 & 0.19 \\
\hline November & -0.0007 & 0.64 & 0.0131 & 0.02 & -0.0076 & 0.00 & -0.0057 & 0.00 & -0.0030 & 0.04 & 0.0058 & 0.01 & -0.0074 & 0.00 & & \\
\hline December & & & 0.0075 & 0.11 & -0.0038 & 0.03 & & & 0.0026 & 0.01 & & & -0.0143 & 0.00 & -0.0051 & 0.00 \\
\hline$\Delta \operatorname{Ln}\left(P_{t-1}\right)$ & 0.3586 & 0.00 & 0.1361 & 0.21 & 0.8040 & 0.00 & 0.3711 & 0.00 & 0.5388 & 0.00 & 0.3890 & 0.00 & 0.3612 & 0.00 & 0.5963 & 0.00 \\
\hline$\Delta \operatorname{Ln}\left(P_{t-2}\right)$ & 0.5046 & 0.00 & 0.5046 & 0.00 & & & 0.2953 & 0.00 & 0.3831 & 0.00 & 0.4174 & 0.00 & 0.5295 & 0.00 & & \\
\hline \multirow[t]{2}{*}{$\Delta \operatorname{Ln}\left(P_{t-3}\right)$} & & & & & 0.0259 & 0.51 & & & & & & & & & & \\
\hline & \multicolumn{2}{|c|}{$\begin{array}{c}T_{t} \geq 2010 \mathrm{M} 4 \\
(n=68)\end{array}$} & \multicolumn{2}{|c|}{$\begin{array}{c}T_{t} \geq 2011 \mathrm{M} 12 \\
(n=48)\end{array}$} & \multicolumn{2}{|c|}{$\begin{array}{c}T_{t} \geq 2011 \mathrm{M} 09 \\
(n=51)\end{array}$} & \multicolumn{2}{|c|}{$\begin{array}{c}T_{t} \geq 2012 \mathrm{M} 01 \\
(n=47)\end{array}$} & \multicolumn{2}{|c|}{$\begin{array}{c}T_{t} \geq 2011 \mathrm{M} 09 \\
(n=51)\end{array}$} & \multicolumn{2}{|c|}{$\begin{array}{c}T_{t} \geq 2010 \mathrm{M} 01 \\
(n=71)\end{array}$} & \multicolumn{2}{|c|}{$\begin{array}{c}T_{t} \geq 2011 \mathrm{M} 11 \\
(n=49)\end{array}$} & \multicolumn{2}{|c|}{$\begin{array}{c}T_{t} \geq 2011 \mathrm{M} 10 \\
(n=50)\end{array}$} \\
\hline January & 0.0344 & 0.00 & & & 0.0095 & 0.38 & 0.0076 & 0.05 & & & & 0.00 & 0.0101 & 0.00 & 0.0044 & 0.22 \\
\hline February & 0.0185 & 0.01 & 0.0514 & 0.00 & 0.0214 & 0.00 & 0.0117 & 0.00 & -0.0134 & 0.00 & -0.0089 & 0.23 & 0.0067 & 0.05 & 0.0075 & 0.00 \\
\hline March & 0.0216 & 0.00 & 0.0503 & 0.00 & & & 0.0145 & 0.00 & 0.0105 & 0.11 & 0.0184 & 0.00 & 0.0139 & 0.01 & 0.0131 & 0.00 \\
\hline April & & & 0.0130 & 0.51 & -0.0065 & 0.03 & & & & & -0.0046 & 0.64 & -0.0040 & 0.15 & & \\
\hline May & & & -0.0533 & 0.00 & -0.0298 & 0.00 & -0.0369 & 0.00 & & & & & -0.0196 & 0.00 & & \\
\hline June & & & -0.0100 & 0.67 & 0.0112 & 0.05 & & & 0.0105 & 0.07 & & & 0.0190 & 0.00 & 0.0304 & 0.00 \\
\hline July & 0.0037 & 0.31 & 0.0022 & 0.89 & 0.0373 & 0.00 & 0.0260 & 0.00 & & & 0.0153 & 0.00 & 0.0227 & 0.00 & 0.0078 & 0.16 \\
\hline August & -0.0105 & 0.05 & 0.0239 & 0.41 & 0.0190 & 0.00 & 0.0217 & 0.00 & -0.0055 & 0.14 & & & -0.0010 & 0.87 & & \\
\hline September & -0.0282 & 0.00 & 0.0384 & 0.00 & & & 0.0140 & 0.00 & & & & & & & 0.0089 & 0.00 \\
\hline October & -0.0273 & 0.00 & -0.0419 & 0.02 & & & -0.0027 & 0.73 & & & & & 0.0010 & 0.88 & 0.0059 & 0.03 \\
\hline November & -0.0140 & 0.01 & -0.0477 & 0.01 & -0.0256 & 0.00 & -0.0072 & 0.28 & 0.0121 & 0.01 & -0.0102 & 0.23 & -0.0049 & 0.12 & & \\
\hline December & & & -0.0505 & 0.03 & 0.0040 & 0.50 & & & 0.0200 & 0.00 & & & -0.0045 & 0.00 & -0.0102 & 0.08 \\
\hline$\Delta \operatorname{Ln}\left(P_{t-1}\right)$ & -0.4657 & 0.00 & -0.5907 & 0.00 & -0.1822 & 0.05 & -0.5779 & 0.00 & -0.1884 & 0.04 & -0.2612 & 0.03 & 0.1741 & 0.16 & 0.1515 & 0.24 \\
\hline $\operatorname{LLn}\left(P_{t-2}\right)$ & -0.3117 & 0.00 & -0.3004 & 0.01 & & & -0.1129 & 0.11 & 0.0078 & 0.95 & -0.1109 & 0.37 & 0.4122 & 0.00 & & \\
\hline$\Delta \operatorname{Ln}\left(P_{t-3}\right)$ & & & & & 0.4613 & 0.00 & & & & & & & & & & \\
\hline $\mathrm{Adj}^{2}$ & 0.542 & & 0.454 & & 0.695 & & 0.535 & & 0.630 & & 0.347 & & 0.757 & & 0.496 & \\
\hline$D W$ & 1.96 & & 2.07 & & 2.16 & & 1.97 & & 2.04 & & 2.01 & & 1.93 & & 2.08 & \\
\hline SIC & -5.815 & & -4.058 & & -6.651 & & -6.455 & & -6.863 & & -5.976 & & -7.090 & & -6.948 & \\
\hline
\end{tabular}

Note: The standard errors of the coefficients (and the resulting $p$-values) were computed using the Newey-West covariance matrix. 
Table 3. The most expensive and cheapest months to buy

\begin{tabular}{|c|c|c|c|c|c|c|c|c|}
\hline \multicolumn{9}{|c|}{ The most expensive months } \\
\hline \multirow{3}{*}{ City } & \multicolumn{4}{|c|}{ Houses } & \multicolumn{4}{|c|}{ Apartments } \\
\hline & \multicolumn{2}{|c|}{ First period } & \multicolumn{2}{|c|}{ Second period } & \multicolumn{2}{|c|}{ First period } & \multicolumn{2}{|c|}{ Second period } \\
\hline & Month & $\%$ rise & Month & $\%$ rise & Month & $\%$ rise & Month & $\%$ rise \\
\hline Adelaide & March & 1.33 & April & 2.17 & April & 1.40 & March & 1.87 \\
\hline Brisbane & January & 0.51 & January & 0.78 & February & 1.13 & August & 0.73 \\
\hline Canberra & September & 1.12 & March & 1.00 & October & 1.45 & August & 0.93 \\
\hline Darwin & March & 1.49 & March & 3.34 & December & 1.16 & December & 1.32 \\
\hline Hobart & January & 0.82 & January & 3.44 & June & 3.06 & February & 5.14 \\
\hline Melbourne & January & 1.05 & July & 3.73 & February & 1.02 & July & 2.60 \\
\hline Perth & March & 0.38 & December & 2.00 & November & 0.58 & March & 1.84 \\
\hline Sydney & February & 2.11 & July & 2.27 & February & 1.01 & June & 3.04 \\
\hline \multicolumn{9}{|c|}{ The cheapest months } \\
\hline \multirow{3}{*}{ City } & \multicolumn{4}{|c|}{ Houses } & \multicolumn{4}{|c|}{ Apartments } \\
\hline & \multicolumn{2}{|c|}{ First period } & \multicolumn{2}{|c|}{ Second period } & \multicolumn{2}{|c|}{ First period } & \multicolumn{2}{|c|}{ Second period } \\
\hline & Month & $\%$ fall & Month & $\%$ fall & Month & $\%$ fall & Month & $\%$ fall \\
\hline Adelaide & October & -0.62 & July & -1.83 & June & -0.53 & December & -2.28 \\
\hline Brisbane & December & -0.19 & May & -0.61 & November & -1.02 & May & -1.20 \\
\hline Canberra & June & -0.53 & December & -0.70 & November & -0.78 & June & -1.25 \\
\hline Darwin & May & -1.53 & June & -3.01 & September & -0.12 & September & -3.76 \\
\hline Hobart & February & -0.50 & September & -2.82 & August & -2.22 & May & -5.33 \\
\hline Melbourne & November & -0.76 & May & -2.98 & November & -0.57 & May & -3.69 \\
\hline Perth & November & -0.30 & February & -1.34 & July & 0.07 & November & -1.02 \\
\hline Sydney & December & -1.43 & May & -1.96 & December & -0.51 & December & -1.02 \\
\hline
\end{tabular}



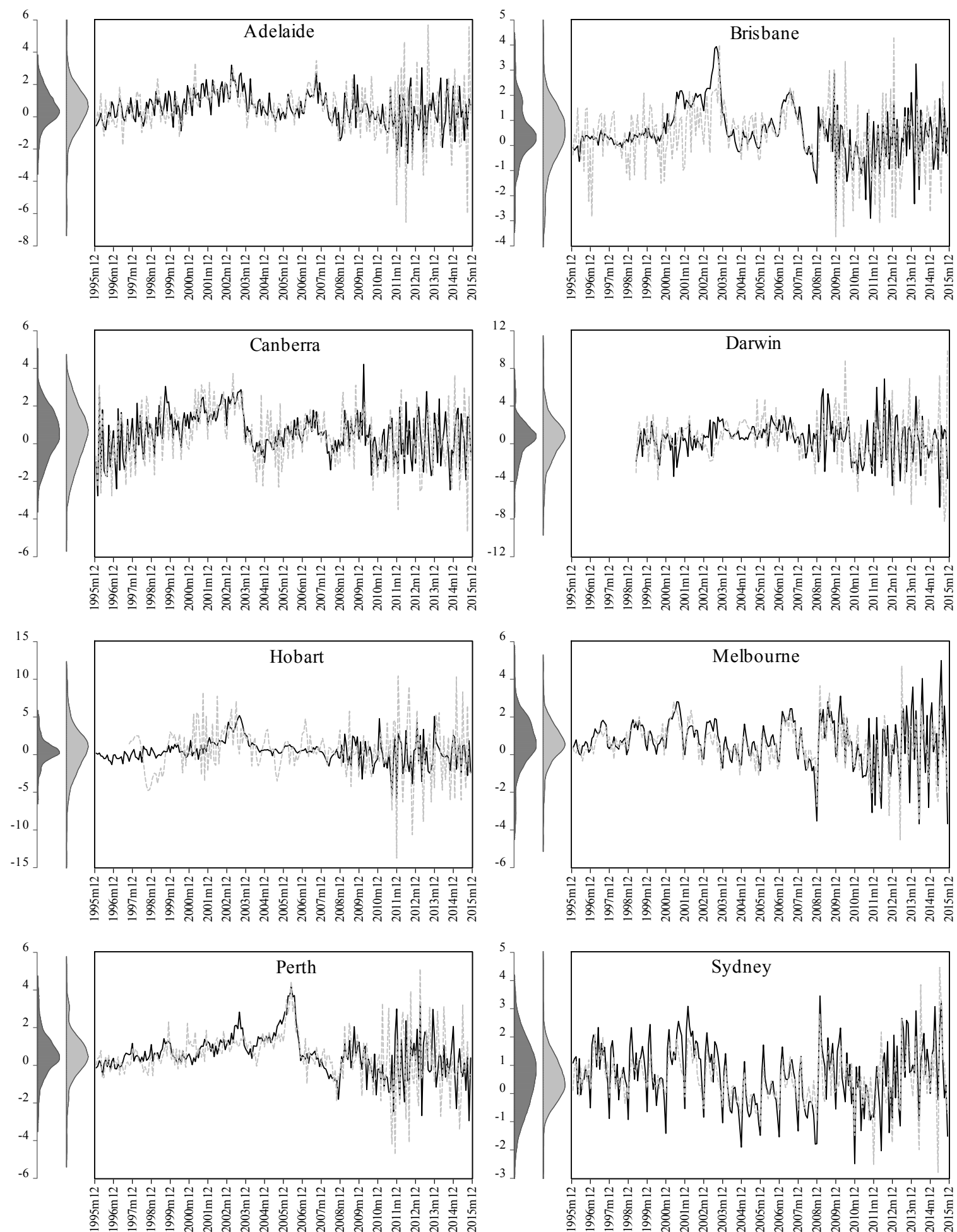

— Monthly growth rate of house prices - Monthly growth rate of apartment prices

Fig.1. Monthly percentage growth rates of house and apartment prices

Notes: Kernel density distribution of the series is shown on the left-hand side vertical axis. 


\section{Supplemental File}

Appendix T1. Testing for equality of means and variances of $\Delta \operatorname{Ln}\left(P_{t}\right)$ using $A B S$ and RP data (1995q1-2015q3)

\begin{tabular}{|c|c|c|c|c|c|}
\hline \multirow[b]{2}{*}{ City } & \multirow[b]{2}{*}{ Description } & \multicolumn{2}{|c|}{ Equality of means } & \multicolumn{2}{|c|}{ Equality of variances } \\
\hline & & $\begin{array}{c}t \\
\text { test }\end{array}$ & $\begin{array}{l}\text { Anova } \\
F \text { test }\end{array}$ & $\begin{array}{c}\text { Levene } \\
F \text { test }\end{array}$ & $\begin{array}{c}\text { Brown-Forsythe } \\
F \text { test }\end{array}$ \\
\hline \multirow[t]{3}{*}{ Adelaide } & $\mathrm{df}$ & 157 & $(1,157)$ & $(1,157)$ & $(1,157)$ \\
\hline & Statistic & -0.06 & 0.00 & 0.29 & 0.07 \\
\hline & $p$-value & 0.95 & 0.95 & 0.59 & 0.80 \\
\hline \multirow[t]{3}{*}{ Brisbane } & df & 157 & $(1,157)$ & $(1,157)$ & $(1,157)$ \\
\hline & Statistic & -0.16 & 0.02 & 0.10 & 0.18 \\
\hline & $p$-value & 0.88 & 0.88 & 0.76 & 0.67 \\
\hline \multirow[t]{3}{*}{ Canberra } & $\mathrm{df}$ & 157 & $(1,157)$ & $(1,157)$ & $(1,157)$ \\
\hline & Statistic & -0.07 & 0.00 & 0.09 & 0.00 \\
\hline & $p$-value & 0.95 & 0.95 & 0.76 & 0.97 \\
\hline \multirow[t]{3}{*}{ Darwin } & df & 143 & $(1,143)$ & $(1,143)$ & $(1,143)$ \\
\hline & Statistic & -0.13 & 0.02 & 2.55 & 2.59 \\
\hline & $p$-value & 0.90 & 0.90 & 0.11 & 0.11 \\
\hline \multirow[t]{3}{*}{ Hobart } & df & 157 & $(1,157)$ & $(1,157)$ & $(1,157)$ \\
\hline & Statistic & 0.23 & 0.05 & 0.36 & 0.31 \\
\hline & $p$-value & 0.82 & 0.82 & 0.55 & 0.58 \\
\hline \multirow[t]{3}{*}{ Melbourne } & $\mathrm{df}$ & 157 & $(1,157)$ & $(1,157)$ & $(1,157)$ \\
\hline & Statistic & -0.08 & 0.01 & 0.63 & 0.64 \\
\hline & $p$-value & 0.94 & 0.94 & 0.43 & 0.42 \\
\hline \multirow[t]{3}{*}{ Perth } & df & 157 & $(1,157)$ & $(1,157)$ & $(1,157)$ \\
\hline & Statistic & 0.02 & 0.00 & 0.43 & 0.39 \\
\hline & $p$-value & 0.98 & 0.98 & 0.51 & 0.53 \\
\hline \multirow[t]{3}{*}{ Sydney } & df & 157 & $(1,157)$ & $(1,157)$ & $(1,157)$ \\
\hline & Statistic & -0.33 & 0.11 & 1.54 & 1.62 \\
\hline & $p$-value & 0.75 & 0.75 & 0.22 & 0.20 \\
\hline
\end{tabular}


Appendix T2. Equality of variances of $\Delta \operatorname{Ln}\left(P_{t}\right)$ pre-and post $G F C$

\begin{tabular}{|c|c|c|c|c|c|}
\hline \multirow[b]{2}{*}{ City } & \multirow[b]{2}{*}{ Description } & \multicolumn{2}{|c|}{ House returns } & \multicolumn{2}{|c|}{ Apartment returns } \\
\hline & & $\begin{array}{l}\text { Levene } \\
(1960) \text { test }\end{array}$ & $\begin{array}{l}\text { Brown-Forsythe } \\
\text { (1974) test }\end{array}$ & $\begin{array}{l}\text { Levene } \\
(1960) \text { test }\end{array}$ & $\begin{array}{l}\text { Brown-Forsythe } \\
\text { (1974) test }\end{array}$ \\
\hline \multirow[t]{3}{*}{ Adelaide } & $\mathrm{df}$ & $(1,237)$ & $(1,237)$ & $(1,237)$ & $(1,237)$ \\
\hline & Statistic & 6.03 & 5.97 & 38.21 & 37.97 \\
\hline & $p$-value & 0.01 & 0.02 & 0.00 & 0.00 \\
\hline \multirow[t]{3}{*}{ Brisbane } & df & $(1,237)$ & $(1,237)$ & $(1,237)$ & $(1,237)$ \\
\hline & Statistic & 4.40 & 5.81 & 14.34 & 14.33 \\
\hline & $p$-value & 0.04 & 0.02 & 0.00 & 0.00 \\
\hline \multirow{3}{*}{ Canberra } & $\mathrm{df}$ & $(1,237)$ & $(1,237)$ & $(1,237)$ & $(1,237)$ \\
\hline & Statistic & 0.15 & 0.16 & 0.63 & 0.67 \\
\hline & $p$-value & 0.69 & 0.69 & 0.43 & 0.41 \\
\hline \multirow[t]{3}{*}{ Darwin } & $\mathrm{df}$ & $(1,197)$ & $(1,197)$ & $(1,197)$ & $(1,197)$ \\
\hline & Statistic & 29.51 & 29.12 & 35.34 & 34.59 \\
\hline & $p$-value & 0.00 & 0.00 & 0.00 & 0.00 \\
\hline \multirow[t]{3}{*}{ Hobart } & df & $(1,237)$ & $(1,237)$ & $(1,216)$ & $(1,216)$ \\
\hline & Statistic & 25.09 & 25.38 & 8.94 & 8.96 \\
\hline & $p$-value & 0.00 & 0.00 & 0.00 & 0.00 \\
\hline \multirow[t]{3}{*}{ Melbourne } & $\mathrm{df}$ & $(1,237)$ & $(1,237)$ & $(1,237)$ & $(1,237)$ \\
\hline & Statistic & 63.99 & 62.95 & 27.57 & 26.18 \\
\hline & $p$-value & 0.00 & 0.00 & 0.00 & 0.00 \\
\hline \multirow[t]{3}{*}{ Perth } & df & $(1,237)$ & $(1,237)$ & $(1,237)$ & $(1,237)$ \\
\hline & Statistic & 11.00 & 10.83 & 30.63 & 30.62 \\
\hline & $p$-value & 0.00 & 0.00 & 0.00 & 0.00 \\
\hline \multirow[t]{3}{*}{ Sydney } & df & $(1,237)$ & $(1,237)$ & $(1,237)$ & $(1,237)$ \\
\hline & Statistic & 5.68 & 5.53 & 13.59 & 13.42 \\
\hline & $p$-value & 0.02 & 0.02 & 0.00 & 0.00 \\
\hline
\end{tabular}


Appendix T3. Zivot and Andrews test results

\begin{tabular}{|c|c|c|c|c|c|c|c|c|}
\hline \multirow{3}{*}{ City } & \multicolumn{4}{|c|}{ House prices and returns } & \multicolumn{4}{|c|}{ Apartment prices and returns } \\
\hline & \multicolumn{2}{|c|}{$\operatorname{Ln}\left(p_{t}\right)$} & \multicolumn{2}{|c|}{$\Delta \operatorname{Ln}\left(p_{t}\right)$} & \multicolumn{2}{|c|}{$\operatorname{Ln}\left(p_{t}\right)$} & \multicolumn{2}{|c|}{$\Delta \operatorname{Ln}\left(p_{t}\right)$} \\
\hline & Min $t$ stat. & Break date & Min $t$ stat. & Break date & Min $t$ stat. & Break date & Min $t$ stat. & Break date \\
\hline Adelaide & -2.93 & 2001:03 & $-5.48^{* * *}$ & 2000:08 & -2.50 & 2010:10 & $-9.85^{* * *}$ & 1999:02 \\
\hline Brisbane & -3.48 & 2001:06 & -4.10 & 2008:03 & -2.94 & 2010:09 & $-9.85^{* * *}$ & 1998:12 \\
\hline Canberra & -3.06 & 2001:01 & $-5.51^{* * *}$ & 1999:03 & -3.69 & 2001:04 & $-9.85^{* * *}$ & 1998:12 \\
\hline Darwin & -3.06 & 2001:01 & $-6.23^{* * *}$ & 2010:09 & -3.69 & 2001:04 & $-14.98^{* * *}$ & 2010:09 \\
\hline Hobart & -4.52 & 2002:12 & $-8.04^{* * *}$ & 2001:07 & -3.53 & 2002:06 & $-16.19^{* * *}$ & 2001:02 \\
\hline Melbourne & -3.31 & 2010:11 & $-7.58^{* * *}$ & 1999:01 & -2.26 & 1999:01 & $-15.43^{* * *}$ & 2013:03 \\
\hline Perth & -2.09 & 2003:01 & $-7.58^{* * *}$ & 1999:01 & -2.33 & 2011:08 & $-15.43^{* * *}$ & 2013:03 \\
\hline Sydney & -2.64 & 2001:01 & $-11.18^{* * *}$ & 2003:11 & -3.23 & 2005:04 & $-15.43^{* * *}$ & 2013:03 \\
\hline
\end{tabular}

Note: ${ }^{* * *}$ indicates that the null hypothesis (i.e. the presence of a unit root) is rejected at the $1 \%$ level.

Appendix T4. Out-of-sample forecasting accuracy (2014m11-2015m11)

\begin{tabular}{|c|c|c|c|c|}
\hline \multirow{3}{*}{ City } & \multicolumn{4}{|c|}{ Monthly growth rate $\Delta \operatorname{Ln}\left(P_{t}\right)$} \\
\hline & \multicolumn{2}{|c|}{ House } & \multicolumn{2}{|c|}{ Apartment } \\
\hline & RMSE & MAE & RMSE & MAE \\
\hline Adelaide & 0.010 & 0.008 & 0.033 & 0.025 \\
\hline Brisbane & 0.009 & 0.008 & 0.013 & 0.012 \\
\hline Canberra & 0.012 & 0.011 & 0.023 & 0.019 \\
\hline Darwin & 0.026 & 0.020 & 0.049 & 0.037 \\
\hline Hobart & 0.020 & 0.018 & 0.059 & 0.053 \\
\hline Melbourne & 0.017 & 0.014 & 0.012 & 0.011 \\
\hline Perth & 0.012 & 0.010 & 0.018 & 0.014 \\
\hline Sydney & 0.010 & 0.008 & 0.016 & 0.013 \\
\hline
\end{tabular}

Notes: (a) The estimated equations in Table 2 are estimated using the sample period $1995 \mathrm{~m} 12-2014 \mathrm{~m} 11$ to generate ex ante forecasts for the period $2014 \mathrm{~m} 11$ 2015m11. (b) RMSE=Root Mean Squared Error. (c) $\mathrm{MAE}=$ Mean Absolute Error. 

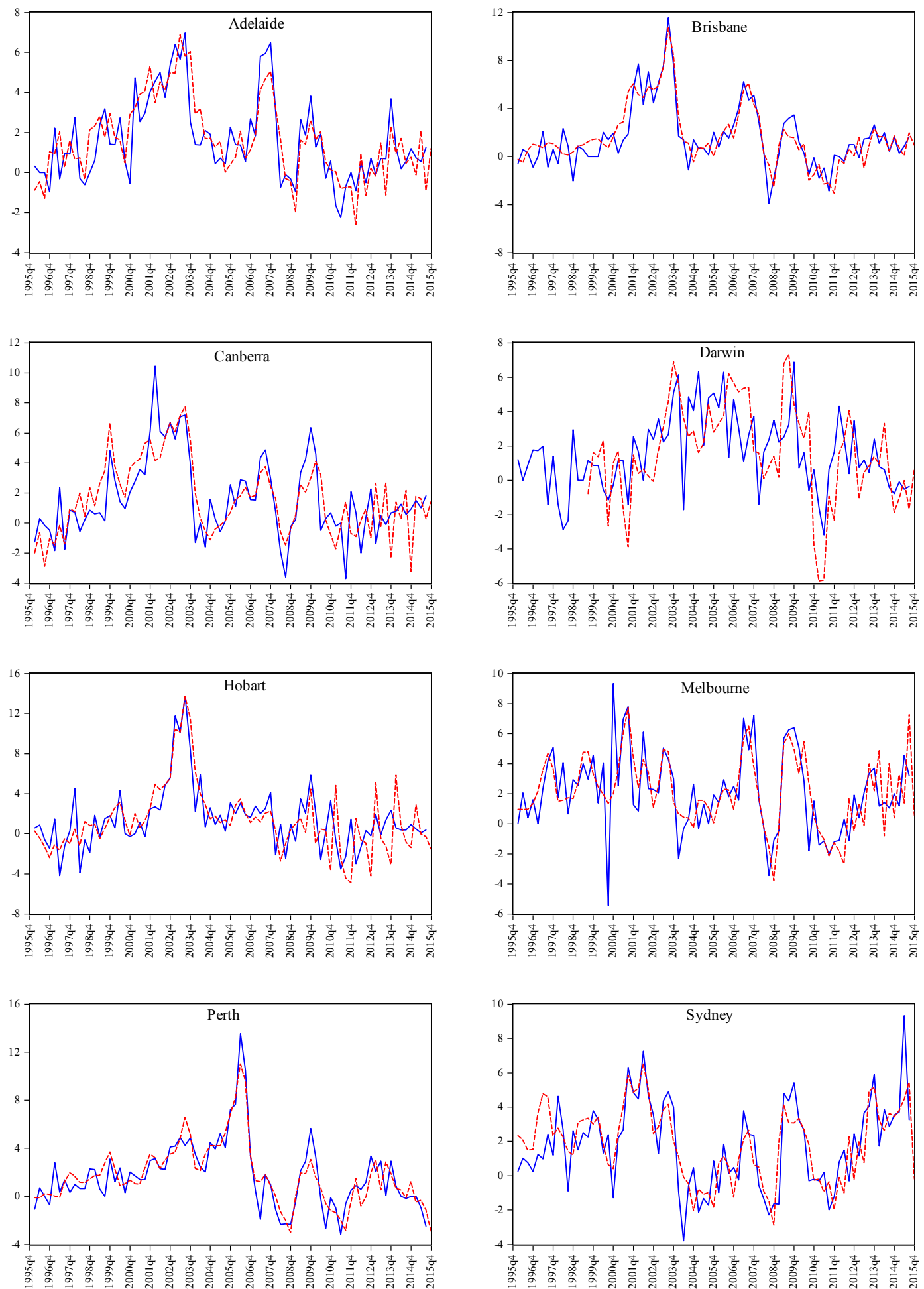

— House price growth rate using ABS data (\%) ----- House price growth rate using CoreLogic data (\%)

Appendix F1. Quarterly percentage growth rate in house prices using $A B S$ and $R P$ data 
House prices
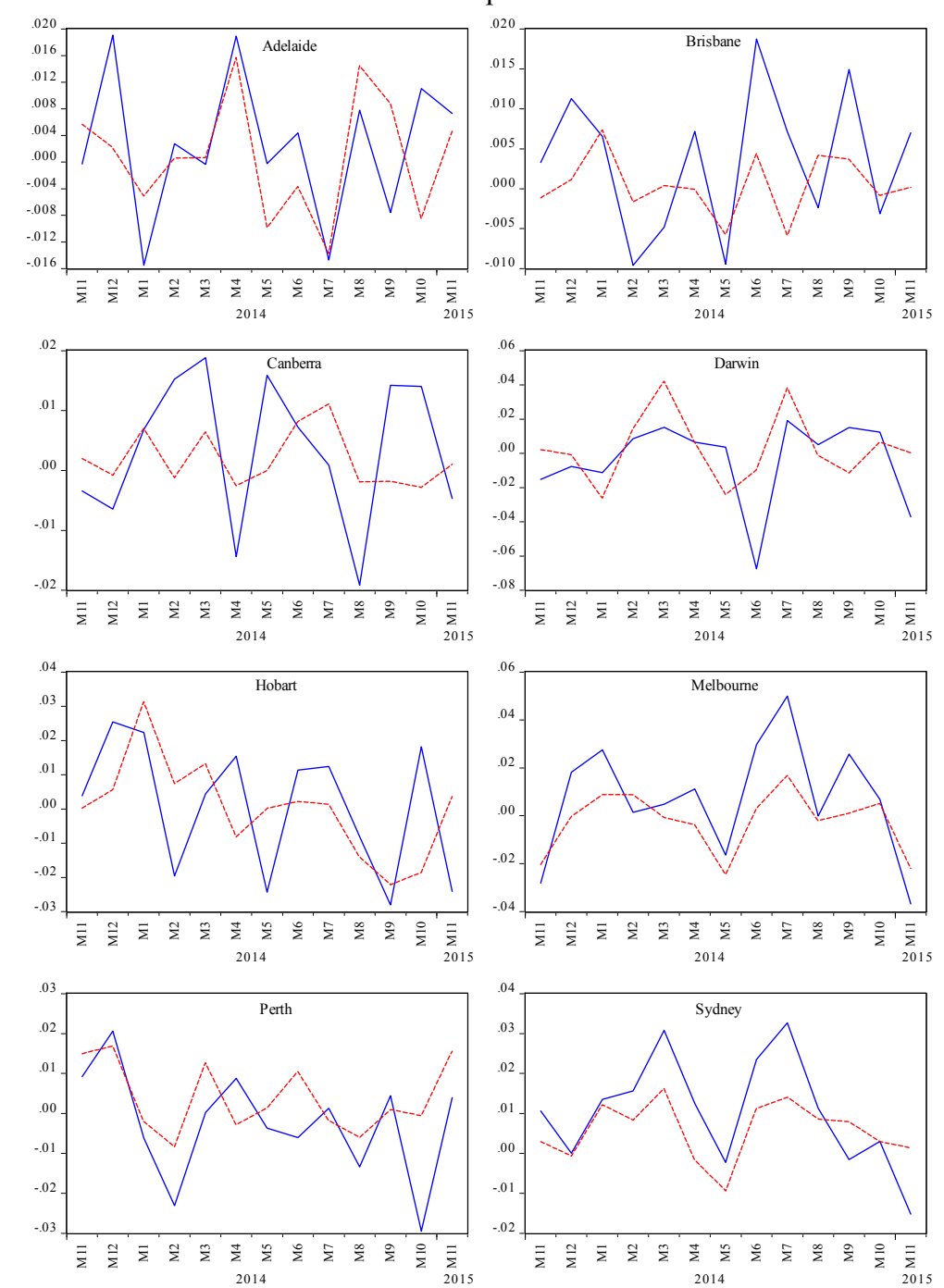

- Actual house price growth (log difference)

Ex re forecting of hos (log differchce)
Apartment prices
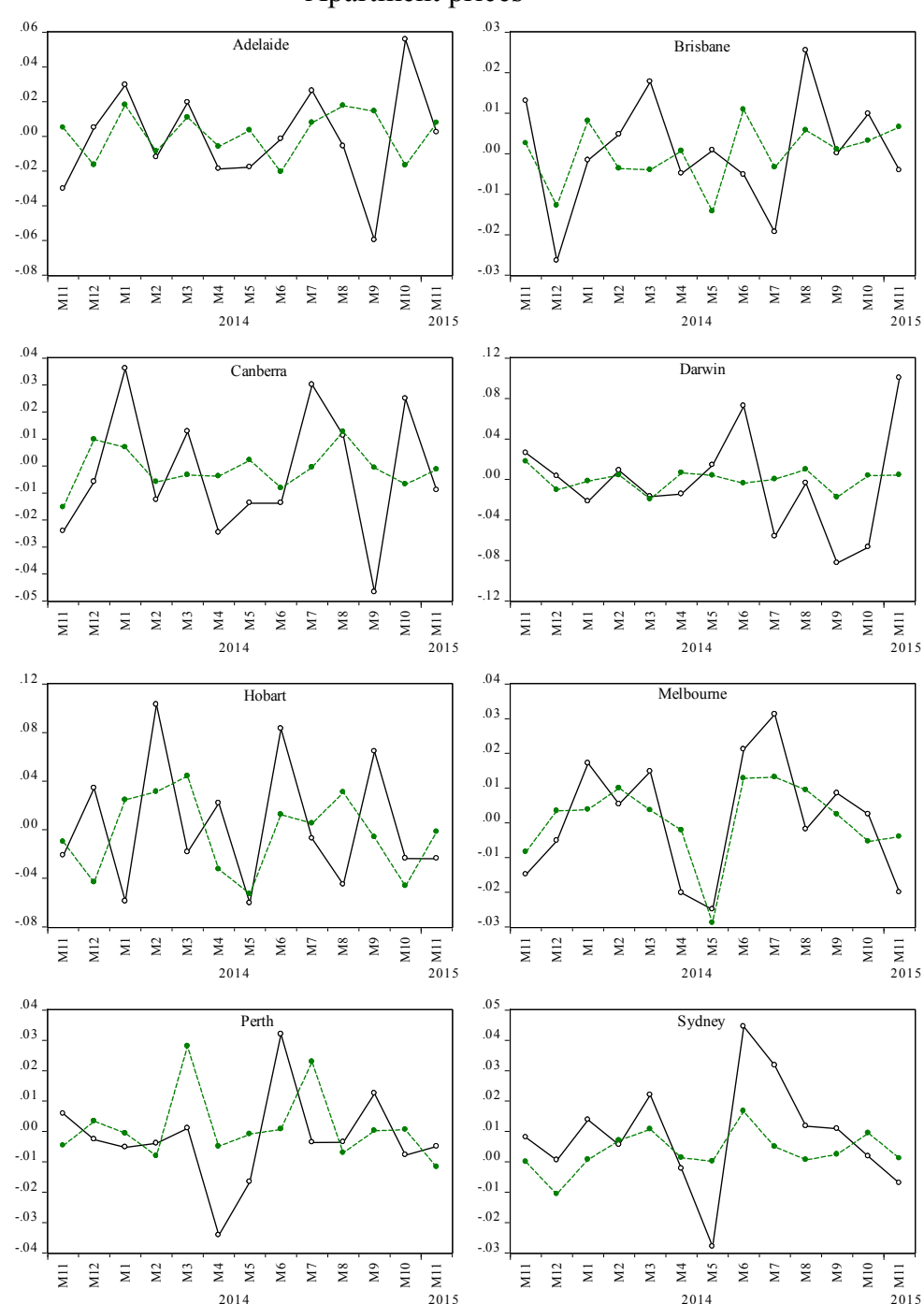

$\multimap$ Actual apartment price growth (log difference)

Alo

Appendix F2. Actual versus out-of-sample forecast of monthly growth in house and apartment prices (2014m11-2015m11 